\title{
Livestock Production and Food Sustainability in East Alego Location, Siaya County, Kenya
}

\author{
Teresa A. Oduor ${ }^{1}$, Charles A. Otieno ${ }^{2}, \&$ Kipkorir W. Tonui ${ }^{3}$ \\ Teacher Ng'iya Mixed Primary School, Ng'iya, Kenya and a student at Jaramogi Oginga Odinga University of Science \\ and Technology, Bondo, Kenya ${ }^{1}$ \\ Dept. of Geography \& Social Sciences-Jaramogi Oginga Odinga University of Science \& Technology, Bondo, Kenya ${ }^{2,3}$ \\ Correspondence: Teresa A. Oduor, Ng'iya Mixed Primary School, P. O. Box 5, Ng'iya, Kenya.
}

\begin{abstract}
A lot of intervention measures have been put in place to curb the challenges faced by peasants practicing subsistence farming. However, most households still experience food unsustainability. Subsistence farmers of East Alego location Siaya County where the study was conducted practice livestock keeping all the year round. Even though the area is endowed with natural conditions favorable for livestock keeping, but most households experience food unsustainability. The main objective of the study was to evaluate the influence of livestock farming on food sustainability. Descriptive research design was used together with research instruments such as observations, interview schedules and administration of questionnaires. The study adopted stratified sampling technique and simple random sampling design with a sample size of 327 households out of 2381 targeted farm households in the study area. Data from the field was analyzed using measures of central tendencies such as mean, mode and median. Frequencies and percentages were also used to present data using tables, bar graphs, line graphs and photographs. Tests such as Spearman`s rank order was used in analyzing data from the field. A spearman's rank correlation value $(r)=0.9$ was closer to 1 and signified a strong/high positive correlation on the benefits of livestock production to farmers. Nearly $81 \%$ of the respondents suggested keeping of mixed animals for their produce and use of dung/farmyard manure as farm input to improve soil fertility so that crop production could be improved for food sustainability. Additionally, respondents (53\%) suggested diversification of income in order to reduce the vulnerability of the households during food shortage periods. There was need for mitigation measures so that subsistence farmers of East Alego location could be able to integrate livestock and crop husbandry practices for food sustainability.
\end{abstract}

Keywords: Subsistence Farming, Food Sustainability, Diversification, Intensification, Livestock Keeping.

\section{INTRODUCTION}

Many authors define a sustainable food system as one that provides healthy food to meet current food needs while maintaining healthy ecosystems that can also provide food for generations to come with minimal negative impact to the environment (American Public Health Association (APHA), 2007; Davids et al., 2016; Foley et al., 2011). Other authors claim that, a sustainable food system also encourages local production and distribution infrastructures and makes nutritious food available, accessible, and affordable (Godfray et al., 2010a; Godfray et al., 2010b; Godfray et al., 2014). According to Andersen (2009), sustainable food security requires not only that all people at all times have access to sufficient food but also that this food be produced with minimal environmental impact (Godfray et al. 2010). Rosane, (2008) puts it that Sustainable food system is humane and just, protecting farmers and other workers, consumers, and communities. Additionally, sustainable food systems are based on principles (ecological, social and economic integrity) that a farmer needs to understand before coming up with innovations in food production (Pretty, 2008; Stenholm, 2016).

Some of the characteristics of sustainable food system are based on Pothukuchi \& Kaufman (1999) findings; sustainable food systems are secure, reliable and resilient to change, accessible and affordable to all members of the society. They are energy efficient, healthy, safe and environmentally beneficial. Works towards organic farming, builds soil quality and farmland through the recycling of organic wastes (Sandhu et al., 2010). Preserves biodiversity in agro ecosystems and has a strong education focus to create awareness of food and agricultural issues (Chrispeels, 1994). This study focused on finding out how livestock farming affects food sustainability in East Alego location, Siaya County, Kenya. From the characteristics, it could be attested that subsistence farmers of East Alego location had a lot do in order to work toward sustainable food system within the community.

Industrial agriculture caused environmental impacts, health problems associated with obesity in the rich world and hunger in the poor world (Garnett 2013). This generated a strong movement towards healthy sustainable eating as a major component of overall ethical consumerism (Mason \& Singer, 2006). The globalization of food production resulted in the loss of traditional food systems in less developed countries, and negative impacts on the people, health, ecosystems and 


\title{
International Advanced Research Journal in Science, Engineering and Technology
}

\author{
Vol. 7, Issue 6, June 2020
}

cultures in those countries (Kuhnlein, 1996). Achieving the goal of enough food production through subsistence farming has been a global challenge. Many modern agricultural practices that were successful elsewhere were not applicable to the complex needs of resource poor- small farming systems (Sands, 1986; Lado 1998). Even though a number of intervention measures had been put in place for food sustainability, but Morgan \& Solarz (1994), puts it that many Sub Saharan African countries do not invest much into agricultural research and development and therefore lack the capacity to adapt modern agricultural practices to local conditions. It is estimated that over one-third of people who live in Latin America, Asia and Africa rely on subsistence agriculture for their food supply (Kostov \& Lingard, 2004). Agricultural productivity levels in Sub-Saharan Africa (SSA) are still far below that of other regions in the world, and are well below that is required to attain sustainable food and poverty reduction goals (Ariga, Kibaara, Olwande \& Jayne, 2009). Peasants take all the necessary steps to ensure proper nourishment of the items they raise (Schlesinger, 1977), but still food sustainability is not realized in many households. FAO (2006), emphasized on drastic measures to help the situation.

The environmental effects of different dietary patterns in the world has brought about unsustainable food systems depending on many factors, including the proportion of animal and plant foods consumed and the method of food production ( Michael \& Baroni, 2007; Steinfeld, et al 2006). The WHO (2004), recommended the Mediterranean diet which is associated with health and longevity and is low in meat, rich in fruits and vegetables. Low in added sugar and limited salt, and low in saturated fatty acids. This is because most people all over the world prefer eating meat, sea food such as shrimps and tuna, and cereals farmed using chemical fertilizers and pesticides which are the ultimate examples given representing unsustainable food (Michael et al. 2007). Types of food recommended for good health by WHO (2004) are produced by subsistence farmers and therefore intervention measures on how farmers should be able to participate in sustainable food production in the area of study was a matter of concern.

Small-scale farming in Kenya accounts for 75 percent of the total agricultural output and 70 per cent of marketed agricultural produce $(\mathrm{GK}, 2010)$. Despite the fact that low income countries such as Kenya tend to have populations in which $80 \%$ of the poor are in rural areas, and more than $90 \%$ of rural households have access to land, majority have insufficient access to sustainable food (de Janvry, 2011). According to Ingle \& Wayazades (1989), size of land holding and annual income is positively and significantly associated with adoption of new technology. However, majority of the peasants $(84.6 \%)$ of East Alego location had access to land acreage of between 0-1, which was not adequate for both crop and livestock production leading to food unsustainability. Improvements that have been made in subsistence farming have not been realized in some regions such as the area of study where peasants are engaged in farm work all the year round, but can only meet their sustainable food needs for four months in a year (Obiero, 2013). Wanjama (2002) points out that, in Kenya the strategic objective is to cut the food unsustainable by 600,000 annually. However, food sustainability in Siaya County is still a challenge although the rural population is engaged in subsistence farming with East Alego location not doing better.

This was unlikely in the area of study as meeting with agricultural extension workers on on-farm visits for agricultural technological methods to the peasants had been a challenge. World Bank (2005) stresses on strategies that can be considered alongside those listed above including; supporting the subsistence farmers to identify niche markets and establish viable market linkages. Promoting small-scale agro-processing and value addition of farm products. Peasants of East Alego location own small farm sizes where farming activities are done throughout the year, with fewer livestock kept. Agricultural methods that have been used in the past years have not been successful on the supply based solutions thus food unsustainability.

\section{MATERIALS STUDIED}

The study involved observation of farm sizes, different livestock kept within the farms, livestock structures and rearing methods. The researcher also used questionnaires and interviews as other main research tools to collect data on the respondents' opinions and attitudes towards sustainable livestock production in East Alego location, Siaya County.

\section{II (1); Description of the study area;}

The study was conducted in East Alego location, Siaya County, Kenya. It covers a surface area of approximately 29.1 square $\mathrm{km}$ with three administrative sub-locations namely; Ulafu, Olwa and Umala (Siaya CIDP 2017). The area lies within the Equator at 0.05'-0.10' and between longitudes 34.263-35 degrees to the east (Counties of Kenya maps 2012). Average land holding is 2 hectares per household. Land tenure is both communally and individually owned (Siaya CIDP, 2017). The drainage is well, soil depth ranges from deep to very deep in some areas, soil texture is fine and the fertility is average (Sombroek, Braun and Van derpouw 1982).

The location is in Low Medium (LM) Agro- ecological zone (AEZ) 1-5\%- soil type being predominantly clay and sandy loam, suitable for crop production but requires incorporation of organic and inorganic manure. The region experiences a modified equatorial climate. It has a bimodal pattern of rainfall with long rains falling between March and June and short rains between September and December with average rainfall of 1000- 1500millimetres per annum (Kenya Meteorological Department, 2017). The area has an altitude of 1300-1500 meters A.S.L. The temperature ranges between $15^{\circ} \mathrm{C}$ and $21^{\circ} \mathrm{C}$ and the evaporation rate is $1800-2000 \mathrm{~mm}$ per year (Siaya County Website Census Report 2009). The 


\title{
International Advanced Research Journal in Science, Engineering and Technology
}

\author{
Vol. 7, Issue 6, June 2020
}

area is characterized by undulating land Features including hills, flat lands holding pastures and agricultural fields and valleys having pastures.

There are few permanent streams traversing the location (GOK, 2005) namely Awach, Wang'e Jawni, Ngongo, Ogongo, Handhalo, Urewe and Kisini found in Olwa Sub-location. Achero, Mtembe and Huludhi flows through Umala Sub-location. Nyambonia and Pundo flows between Umala and Ulafu Sub-locations respectively, while Nywinje flow through Ulafu Sub-location. Majority of the farmers in the area of study use water from these streams for domestic chores. Livestock kept include dairy cows, zebu cows, local goats and sheep and local poultry as the most outstanding ones (Siaya CIDP, 2017).

\section{METHODOLOGY}

The study adopted descriptive research design (Kothari, 2004). The study was carried out in randomly selected households covering livestock production in relation to food sustainability within the location. Direct observations, interviews and questionnaires were used as the main tools for collecting data. These facilitated collection of data on the views, perceptions, attitudes, opinions and behavior of the respondents (Cuavery et al, 2007; Oso \& Onen, 2005). Quantitative data collected was about households practicing livestock farming, farm sizes, livestock types and peasants with livestock structures (Siaya CIDP, 2017).

Direct observation was important as it provided data on what farmers actually do as opposed to what they said they did. It also allowed for first- hand information to the researcher without informants (Yuko \& Owen, 2005). Observations were on grazing fields and established pastures for zero-grazing, types of livestock kept, methods of rearing used and livestock structures. The researcher also used Spearman's rank order to analyze data from the field. There was need for mitigation measures as farmers associated large tracks of land with increased livestock production and least considered adoption of new technology for improved and diversified production resulting to food unsustainability. A spearman's rank correlation value $(r)=0.9$ was closer to 1 and signified a strong/high positive correlation on the benefits of livestock production to farmers. Mitigation measures for upgrading of livestock in the area of study for food sustainability could be put in place leading to food sustainability. It can therefore be concluded that livestock production in the three Sub-locations could do well with diversification and intensification, and thus intervention measures on integrating livestock and crop husbandry in the East Alego location could lead to food sustainability.

\section{RESULTS AND DISCUSSIONS}

Table I: Land acreage owned by subsistence farmers in East Alego location $(\mathrm{N}=317)$

\begin{tabular}{ccc}
\hline Land acreage owned & No. of respondents & percentage $(\%)$ \\
\hline $0-0.5$ & 148 & 46.7 \\
$0.6-1$ & 120 & 37.9 \\
$1.5-2$ & 35 & 11.0 \\
$2.5-3$ & 6 & 1.9 \\
$3.5-4$ & 8 & 2.5 \\
Total & 317 & 100 \\
Mean acreage owned & & 0.8 \\
\hline
\end{tabular}

Nearly half of the respondents (46.7\%) owned 0-0.5 acres of land while more than a third (37.9\%) owned 0.6-1 acres of land (Table I). 2.5 and above acres of land was owned by negligible (4.4\%) percentages of the respondents (Table I). Majority of peasants $(84.6 \%)$ had access to land acreage of between $0-1$ which was used for both crop production and animal rearing. The mean land acreage was 0.8 with a modal value of 0-0.5 acres. Lowder (2014) supports that, size of land holding and annual income is positively and significantly associated with the adoption of new technology in farming. Respondents with less than 1 acre of land (Table I) cited need of more acres for extensive farming. There was need for mitigation measures as the peasants associated large tracks of land with increased production and least considered adoption of new technology for improved and diversified production resulting to food unsustainability.

\section{IV (1); Livestock farming and food sustainability in East Alego location Siaya County}

This section evaluated how livestock farming affected food sustainability in East Alego location Siaya County. It was aimed at finding out the number of animals kept by the respondents, types of poultry kept and other types of farming practiced for food sustainability. The methods of rearing the respondents practiced and reasons for choosing the methods and importance of livestock keeping in relation to food sustainability.

Majority of respondents in Olwa and Umala Sub-locations had between 1-2 cattle, unlike in Ulafu Sub-location where almost half of the respondent had between 3-4 cattle (Fig. 4.3). In the three Sub-locations no respondent was keeping a herd of cattle or a flock of sheep. Study findings revealed that the majority of farmers owned between 0-1 acreage of land (Table I) which according to the respondents could not be enough for both crop production and livestock keeping. Fewer respondents were keeping cattle more than six in the three sub-locations (Fig.1). 


\section{International Advanced Research Journal in Science, Engineering and Technology}

Vol. 7, Issue 6, June 2020

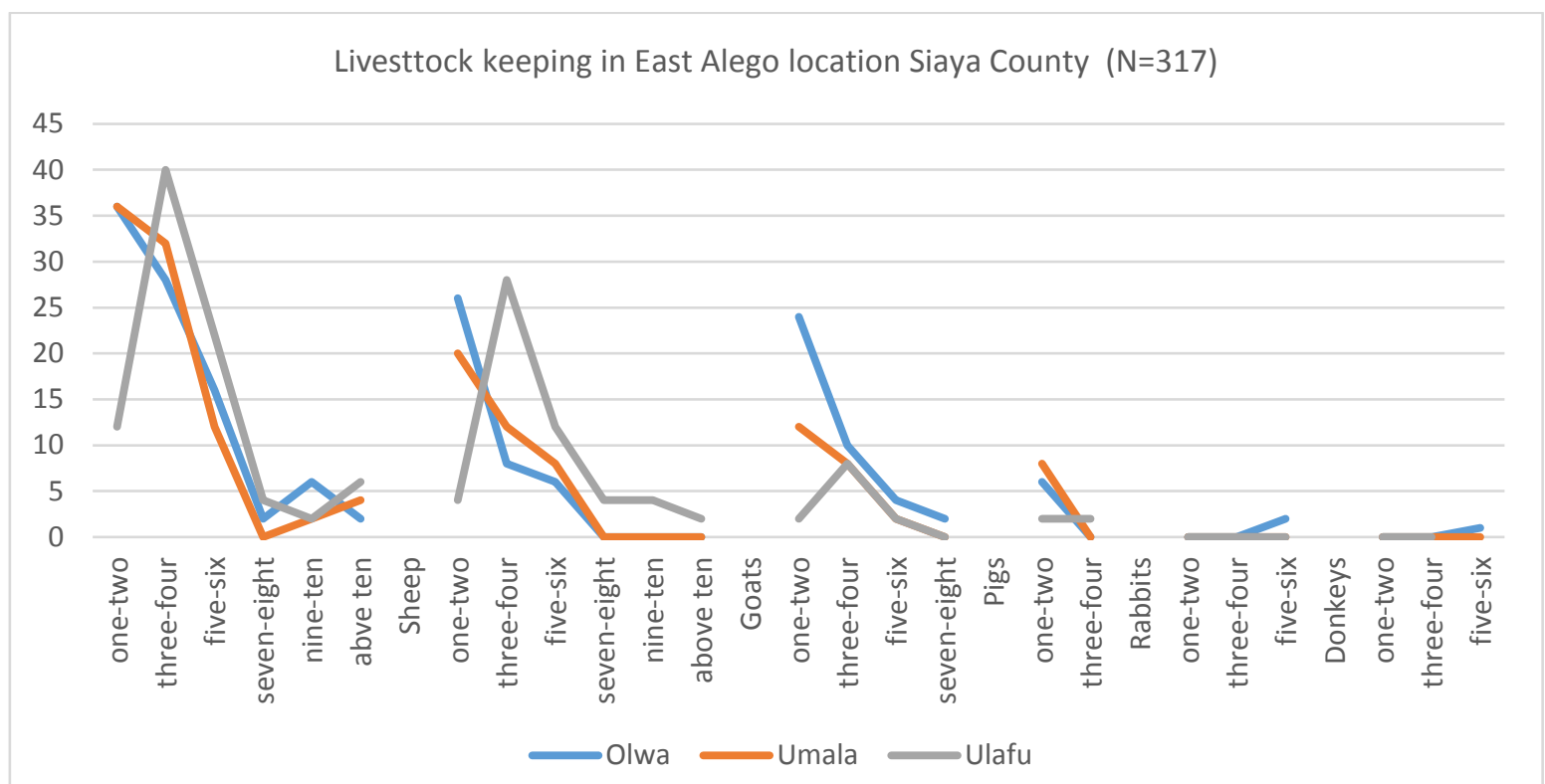

Fig.1: A bar graph shows the no. of livestock kept by farmer in East Alego location (n=317). Source: Researcher, (2019)

Olwa sub-location had more respondents owning goats unlike in Ulafu Sub-location where the respondents owning goats were very few (Fig.1). Through interviews respondents preferred keeping of sheep to goats due to management in grazing. Study findings revealed that sheep could graze on grass inside or around the home while goats were to be gazed in the bushy areas thus large acreage of land which most respondents attested to not owning. All the three Sub-locations had respondents owning fewer number of goats, Pigs and donkeys (Fig. 1). Rabbits farming was not embraced by many respondents a part from Olwa Sub-location where the number kept by a minority hardly exceeded six (Fig.1). The most outstanding poultry kept by majority of farmers was chicken as shown in Figure 4.4 below.

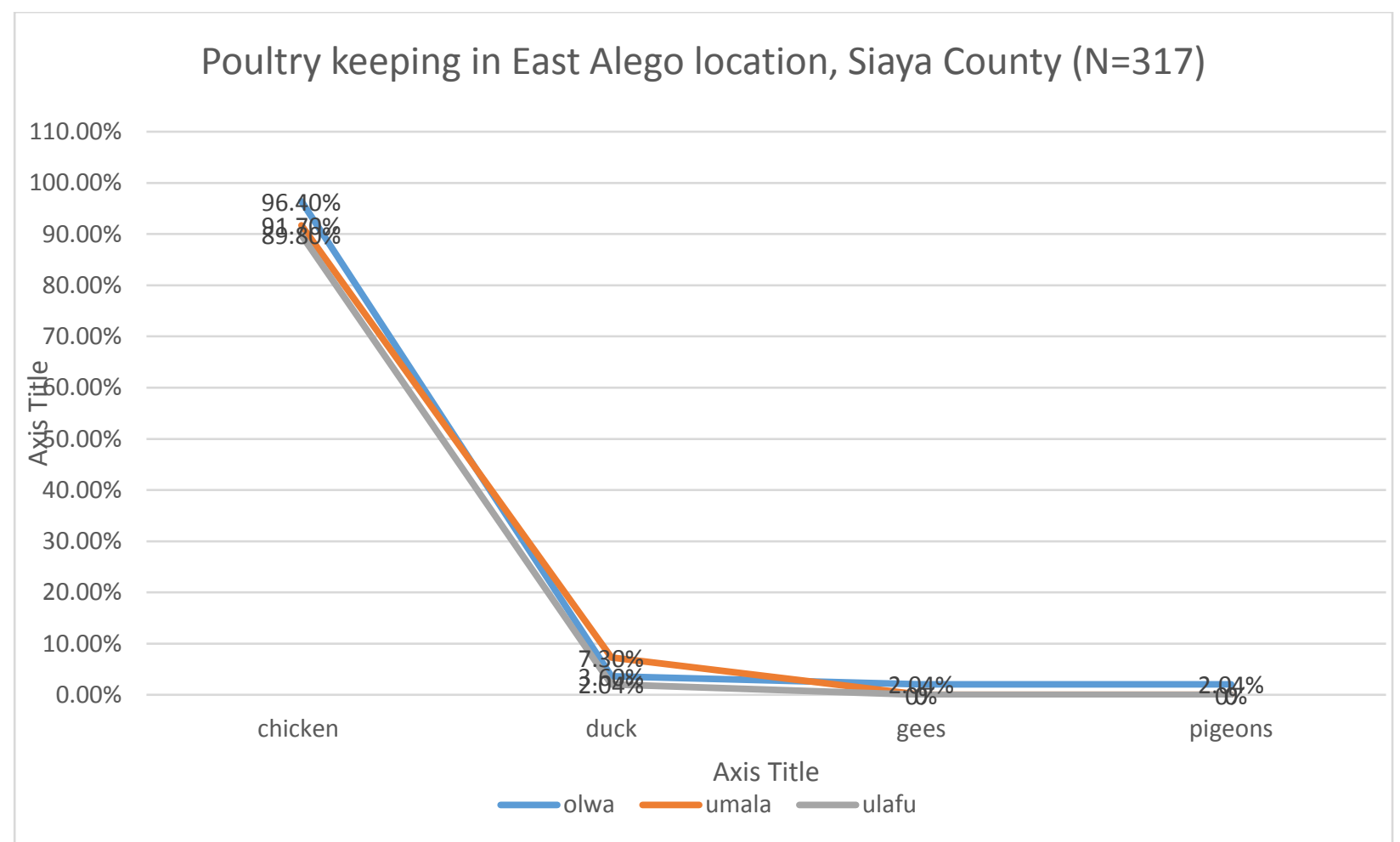

Fig. 2: A line graph showing Poultry keeping in East Alego location, Siaya County. Source: Researcher, (2019)

Olwa Sub-location had the highest number of respondents keeping chicken (96\%) while Umala (92\%) and Ulafu $(90 \%)$ Sub-locations were almost at the same range (Fig. 2). Ducks were kept by fewer respondents in the three Sublocations. However, gees (2.04\%) and pigeons (2.04\%) were only kept in Olwa Sub-location at very low percentages 


\title{
International Advanced Research Journal in Science, Engineering and Technology
}

\author{
Vol. 7, Issue 6, June 2020
}

(Fig.2). Respondents mentioned a number of benefits from poultry keeping such as provision of eggs and meat from the chicken and ducks for home consumption while the main reason was sale of the preferred poultry. Study findings revealed that more sales of poultry influenced food sustainability as home consumption was not so much given preference by the respondents. Through interviews, the respondents affirmed that the rest of the animals and some of the poultry kept and their products apart from donkeys were mainly for sale.

The respondents further attested that the animals and poultry droppings were of great importance in improving the farms fertility. However, very few farmers made use of the droppings on their farms citing lack of labour resulting to overuse of inorganic manure which over a time impoverished the soils leading to low quality harvests. Study findings further revealed that livestock keeping was a great source of livelihood to the respondents even though relating it to food sustainability was a challenge that needed mitigation measures. According to the respondents, livestock rearing methods used depended on the type and number of livestock kept and most importantly time allocated by the farmer to attend to the livestock. Even though the majority owned only 0-1 acres of land (Table I), but the issue of pasture for farmers practicing semi- intensive methods of rearing was not attached to individual land ownership as most herders trespassed to other peoples land. Farmers practicing intensive method of rearing had established pastures and had fewer dairy animals. Figure 3 shows the types of rearing methods that were used by different the farmers.

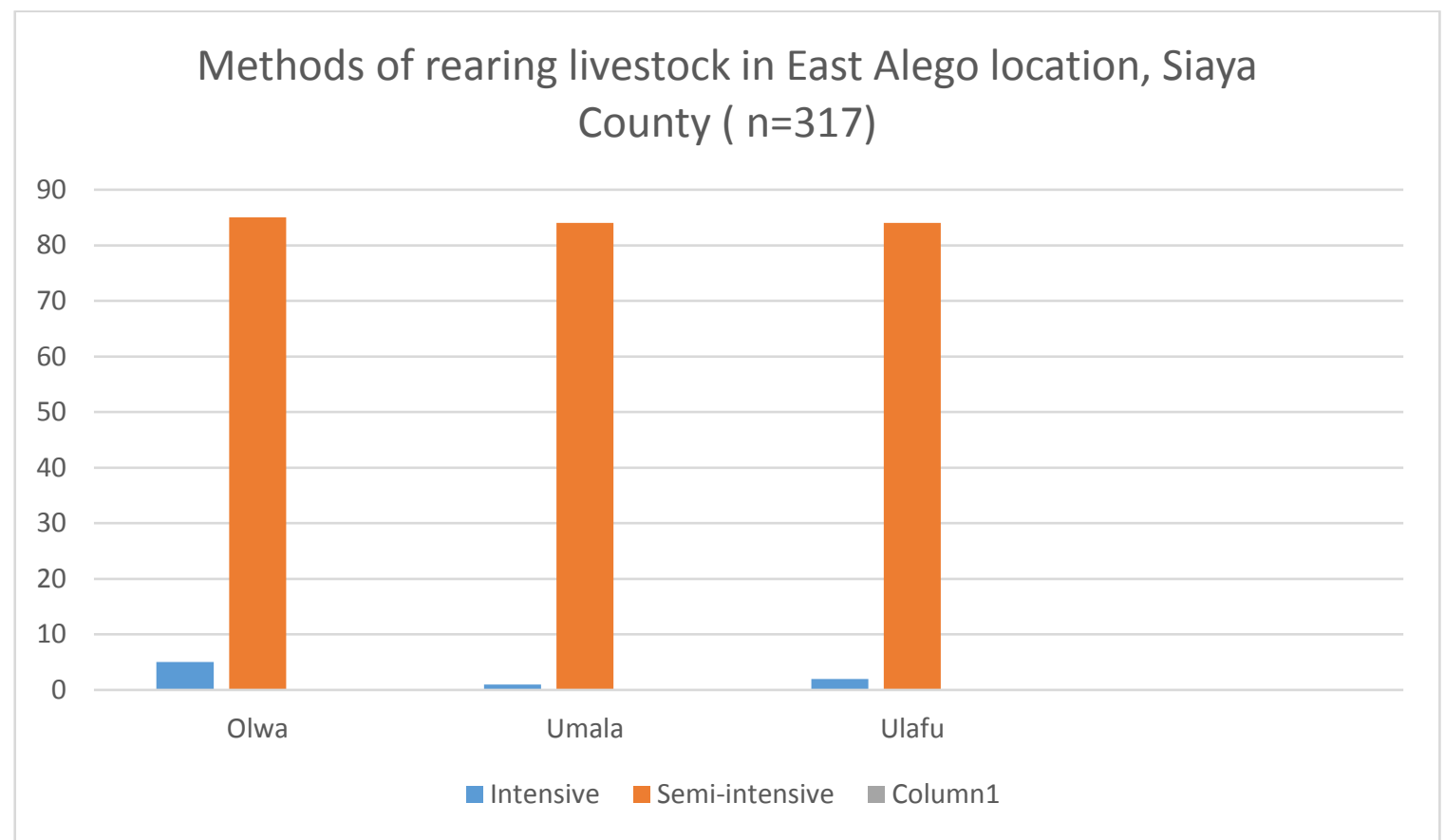

Fig.3: A bar graph showing the methods of livestock rearing used in East Alego location Siaya County (n=317).

Source: Researcher, (2019)

Majority of the respondents in Olwa Sub-location (85) used semi-intensive method of rearing livestock while Umala (84) and Ulafu (84) Sub-locations had the same number of respondents using semi-intensive (free range/herding) method of rearing. This was because most farmers in the three Sub-locations kept traditional animals and only a few practiced dairy farming and hence very low percentage used intensive method of rearing livestock. Choice of rearing methods depended on the number of animals one had and the types of animals kept. An analysis done by Pretty, (2008) indicates that at least $25 \%$ of poultry and pig meats are produced under the landless intensive systems whereas, $19 \%$ and $56 \%$ being under the land based extensive and mixed crop livestock systems respectively in SSA with minimal space requirement as many farmers do not have enough land.

Observational studies revealed that many farmers were practicing free range (herding) method of rearing with very low numbers of livestock. If farmers of East Alego location could diversify livestock breeds and intensify management then they would be working towards food sustainability. Livestock keeping in East Alego location is mainly of local breeds especially goats, sheep and cattle. The most outstanding benefit from these animals is farmyard manure with low milk production. Percentage of farmers keeping draft animals is very low, and this the respondents attributed to small pieces of land owned. This has not stimulated agricultural production which would firstly lead to national self-sufficiency in food supplies and secondly to economic growth raising the living standards of the peasants.

IV (2); Reasons for choosing livestock farming methods in East Alego location, Siaya County

This section was particularly on finding out the reasons as to why farmers in East Alego location practiced the methods of livestock rearing cited in Fig. 3. Some of the reasons that were mentioned by the respondents are shown on Table II. 


\section{International Advanced Research Journal in Science, Engineering and Technology}

Vol. 7, Issue 6, June 2020

Table II: Reasons for choosing livestock rearing methods by farmers in East Alego location Siaya County (N=317)

\begin{tabular}{lcc|cc|cc|ccc}
\hline Characteristics & Olwa & $\%$ & \multicolumn{2}{c|}{ Umala $\%$} & Ulafu & $\%$ & \multicolumn{2}{c}{ Total } & $\%$ \\
\hline Adequate land & 11 & 10 & 6 & 5.5 & 10 & 10.2 & 27 & 8.5 \\
Easier to manage & 42 & 38.2 & 34 & 31.2 & 40 & 40.8 & 116 & 36.6 \\
To be responsible & 5 & 4.5 & 8 & 7.3 & 7 & 6.4 & 20 & 6.3 \\
To be fully engaged & 9 & 8.2 & 7 & 6.4 & 5 & 4.5 & 21 & 6.6 \\
Duties of other family members & 8 & 7.3 & 12 & 11 & 10 & 10.2 & 30 & 9.5 \\
For proper record keeping & 2 & 1.8 & 1 & 0.9 & 1 & 0.9 & 4 & 1.3 \\
For profitability & 20 & 18.2 & 30 & 27.5 & 18 & 18.4 & 68 & 21.4 \\
Enough materials for structure & 13 & 11.8 & 11 & 10 & 7 & 6.4 & 31 & 9.8 \\
\hline
\end{tabular}

Source: Researcher, (2017)

More than a third (36.6\%) of the respondents in all the Sub-locations had a reason of easier management in choosing their method of rearing livestock. During the interviews respondents practicing semi intensive method of rearing livestock cited liberty at managing the animals. This was due to balancing of their time on when to tender for the animals and when to attend to other family duties for the household livelihood (Table II). Livestock kept were beneficial to the farmers and therefore profitability $(21.4 \%)$ was also a matter of concern to almost a quarter of the respondents in the three Sub-locations (Table II). Fewer farmers had put up designated structures (9.8\%) for their livestock (Table II).

Observational studies revealed that most respondents kept their cows in the open area within the homestead while farmers keeping goats and sheep had constructed structures to be used after grazing. In most households respondents cited that livestock management should be for all family members although only $9.5 \%$ households revealed this. The rest of the reasons had low percentages such as adequate land (8.5\%) because majority of the respondents owned less than an acre (Table I) but were keeping livestock. As a way of balancing livestock management and crop tending $6.6 \%$ suggested full engagement of subsistence farming activities thus adopting livestock-crop integration. To some respondents (6.3\%), this was a way of being responsible in sustainable food production.

According to the respondents record keeping (1.3\%) had low response because most respondents had few traditional livestock that were not very much productive but awaited sales when household challenges occurred to reduce vulnerability. Study findings further revealed that most traditional cows were not milked and thus in normal circumstances the sure benefit from them was their droppings and the calves that they took a number of years to bring forth. This notwithstanding took time to translate into food sustainability. Besides using livestock droppings as farmyard manure, respondents cited varied benefits from livestock keeping that could be used for food sustainability. Table III shows some of the benefits the respondents cited.

Table III: Benefits from livestock keeping in East Alego location Siaya County (N=317)

\begin{tabular}{|c|c|c|c|c|}
\hline Characteristic & Olwa $(n=110)$ & Umala $(n=109)$ & Ulafu $(n=98)$ & Total (317) \\
\hline Provision of meat & 12 & 7 & 6 & 25 \\
\hline Milk/eggs for consumption & 8 & 9 & 7 & 22 \\
\hline Selling livestock & 25 & 22 & 18 & 65 \\
\hline Draft animals & 4 & 5 & 4 & 13 \\
\hline Farmyard manure & 30 & 35 & 32 & 97 \\
\hline Environmental cleanliness & 3 & 2 & 1 & 6 \\
\hline Cultural & 12 & 10 & 9 & 31 \\
\hline Prestige & 0 & 0 & 0 & 0 \\
\hline Selling livestock products & 10 & 12 & 13 & 35 \\
\hline Source of livelihood & 6 & 7 & 8 & 21 \\
\hline
\end{tabular}

Source: Researcher, (2019)

More than a third of the respondents acknowledged that their major benefit from livestock keeping was farmyard manure (97) which they used to improve soil fertility in crop production (Table III). Reijntjes, (1992) puts it that, sustainable agriculture refers to an approach, which is ecologically sound, economically viable, socially just, humane and adaptable. It means successful management of resources for agriculture to satisfy changing human needs while maintaining or enhancing the quality of environment and conserving natural resources. This is in line with farmers making use of animal droppings to improve the quality of soil in their farms for improved production hence food sustainability. There is need to work in harmony with nature to maintain ecological balance. Respondents also cited sales of livestock (65) and sales of livestock products (35) as another important benefit from livestock keeping (Table III). 


\section{International Advanced Research Journal in Science, Engineering and Technology}

Vol. 7, Issue 6, June 2020

The rest of the benefits had low percentages and depended with individual farmers apart from milk and eggs consumption (22) which was mentioned by almost an eighth of the respondents for food sustainability in the provision of animal proteins (Table III). According to the respondents fewer farmers used poultry for provision of meat (25). Winrock, (1992) upholds that animals are an important source of food, particularly of high quality proteins, vitamins, minerals and micronutrients. Animal products are a source of disposable income for many smallholder farmers in developing countries. They are often the most important cash crop in many small holder mixed farming systems. As Saini, (1989) puts it, cash can be generated from sales of livestock products regularly or occasionally. The study findings revealed that a number of farmers benefited from farmyard manure and livestock sales more than livestock products.

The study adopted Spearman's rank correlation to establish the nature of relationship between livestock keeping and how the respondents benefited in relation to sustainable food in Olwa Sub-location and Umala/Ulafu Sub-locations of East Alego location.

Table IV: A Spearman's rank correlation order showing the benefits of livestock keeping in Olwa and Umala/Ulafu Sub-locations $(n=317)$

\begin{tabular}{lccc|ccc}
\hline & Olwa & & & Umala/Ulafu & \\
Characteristics & values & Ranks & values & Ranks & d & d2 \\
\hline Provision of meat & 12 & 3.5 & 6.5 & 7 & -3.5 & 12.25 \\
Milk/eggs consumption & 8 & 6 & 8 & 5 & 1 & 1 \\
Selling livestock & 25 & 2 & 20 & 2 & 0 & 0 \\
Draft animals & 4 & 8 & 4.5 & 8 & 0 & 0 \\
Farmyard manure & 30 & 1 & 33.5 & 1 & 0 & 0 \\
Environ. Cleanliness & 3 & 9 & 1.5 & 9 & 0 & 0 \\
Cultural purpose & 12 & 3.5 & 9.5 & 4 & -0.5 & 0.25 \\
Prestige & 0 & 10 & 0 & 10 & 0 & 0 \\
Livestock products & 10 & 5 & 7.5 & 6 & 1 & 1 \\
\hline
\end{tabular}

Source: Researcher, (2019)

Spearman's rank correlation $r=1-\frac{6 \sum d^{2}}{n\left(n^{2}-1\right)}$

$$
\begin{gathered}
r=1-\frac{6 \times 14.5}{9\left(9^{2}-1\right)} \\
r=1-\frac{87}{720}=0.879 \\
r=0.9
\end{gathered}
$$

Through calculations above (Table IV) it shows that the Spearman's rank correlation $(r)=0.9$. This value is closer to 1 and it signifies a strong/high positive correlation on the benefits of livestock production to farmers of East Alego location. The challenge was on how these farmers could upgrade their livestock to acquire more benefits in order to be food sustainable.

\section{IV (3); Effects of food sustainability experienced by farmers in East Alego location}

Despite the fact that farmers of East Alego location practiced subsistence farming all the year round but, they still cited a number of effects of food sustainability as shown on table $\mathrm{V}$ below.

\begin{tabular}{|c|c|c|c|c|c|c|c|c|}
\hline \multirow[t]{2}{*}{ Characteristics } & \multicolumn{8}{|c|}{ respondents' } \\
\hline & Olwa & $\%$ & Umala & $\%$ & Ulafu & $\%$ & Total & $\%$ \\
\hline Poor crop yields & 15 & 13.6 & 13 & 11.9 & 12 & 12.2 & 40 & 12.6 \\
\hline Low livestock production & 20 & 18.2 & 22 & 20.2 & 19 & 19.4 & 61 & 19.2 \\
\hline Malnutrition esp. in children & 5 & 4.6 & 4 & 3.7 & 3 & 2.7 & 12 & 3.8 \\
\hline Shortage of commodities & 20 & 18.2 & 24 & 22 & 18 & 18.4 & 62 & 19.6 \\
\hline Hiking of food prices & 45 & 40.9 & 35 & 32.1 & 38 & 38.8 & 118 & 37.2 \\
\hline Unemployment & 3 & 2.7 & 7 & 6.4 & 5 & 4.6 & 15 & 4.7 \\
\hline Migration & 2 & 1.8 & 4 & 3.7 & 3 & 2.7 & 9 & 2.8 \\
\hline
\end{tabular}

Table V: Effects of food sustainability cited by farmers in East Alego location Siaya County $(\mathrm{N}=317)$

Source: Researcher, (2019)

More than a third of the respondents in all the Sub-locations emphasized on hiking of food prices (37.2\%) followed by shortage of commodities $(19.6 \%)$ as impacts of food unsustainability (Table V). Slightly more than one tenth 


\section{International Advanced Research Journal in Science, Engineering and Technology}

Vol. 7, Issue 6, June 2020

experienced low livestock production (19.2\%) and poor crop yields (12.6\%) (Table V). Respondents were not comfortable with the interviews on malnutrition (3.8\%) especially in children therefore, very few responded. Unemployment $(4.7 \%)$ cited by respondents was basically attached to farm work. Very few responded on migration $(2.8 \%)$ as they did not consider some of the family members migrating to urban areas in search of employment having a reason of food unsustainability but general livelihood of the household members (Table V).

The study findings revealed that majority of the respondents suffered hiking of food prices when there was shortage of commodities in the market. Further findings revealed that the impact was severe. Most commodities in the market sold were seasonally brought in from other regions within the country. This resulted to hiking of prices to meet the traders' costs. There is need for mitigation measures so that farmers should not suffer to acquire what they could produce within the location at hiked prices as this leads to food unsustainability. Diversification and intensification in crop production and livestock farming needs to be practiced to locally strengthen food sustainability situation in the area of study. Table VI shows some of the respondents' responses on ways of managing the situation.

Table VI: Strengthening food sustainability situation $(\mathrm{n}=317)$

\begin{tabular}{l|cc|cc|cc|cc}
\hline Characteristics & \multicolumn{7}{|c}{ respondents } \\
\cline { 2 - 9 } & Olwa & $\%$ & Umala & $\%$ & Ulafu & $\%$ & Total & $\%$ \\
\hline Use of dung/organic manure & 50 & 45.5 & 37 & 33.9 & 41 & 42 & 128 & 40.4 \\
Storage of fodder & 15 & 13.6 & 20 & 18.4 & 16 & 16.3 & 51 & 16.1 \\
Cropping across slopes & 5 & 4.5 & 10 & 9.2 & 12 & 12.3 & 27 & 8.5 \\
Intercropping cereals & 22 & 20 & 23 & 21.1 & 17 & 17.3 & 62 & 19.6 \\
Practice of agroforestry & 17 & 15.5 & 17 & 15.6 & 11 & 11.2 & 45 & 14.2 \\
Adoption of zero tillage & 1 & 0.9 & 2 & 1.8 & 1 & 0.9 & 4 & 1.2 \\
\hline
\end{tabular}

Source: Researcher, (2019)

On how the peasants would manage food unsustainability situation and locally use whatever they had at their disposal for improved food production, averagely $40 \%$ suggested use of dung / organic manure as farm input to improve soil fertility so that crop production could be improved for food sustainability (Table VI). Respondents also suggested storage of fodder/farm residues and household wastes for feeding animals in dry periods so that the animals would not suffer and hence have quality produce for sustainable food (Table VI). More than a third of the respondents cited intercropping cereals such as maize with nitrogen fixing legumes as a way of improving crop production (Table VI). Minority of the respondents cited practice of agroforestry and adoption of zero tillage (Table VI). The research findings revealed that nearly $20 \%$ of the respondents were not suggesting use of dung/organic manure which could improve the soil fertility for improved crop production but relied on intercropping of cereals which would not improve yield if the soil was not fertile. A Spearman's rank correlation on comparison of benefits of livestock to the farmers of East Alego location showed a high positive correlation with $(r)=0.9$. This value signified a strong/high positive correlation on the benefits of livestock production to farmers. Hence there was need for upgrading of livestock in the area of study so that farmers could acquire more benefits in order to be food sustainable

\section{CONCLUSION}

Livestock are like a cash crop to peasants of East Alego location. Even though the number kept is low but, upgrading of the existing breeds kept could lead to sustainable food. Correlation of $r=0.9$, denoted a strong positive relationship on the benefits to the peasants in relation to average land holding in East Alego location

\section{RECOMMENDATIONS}

Farmers should be advised on upgrading of livestock. This could help in the production of high-quality milk, eggs and early maturing livestock to improve the farmer's production for food sustainability.

\section{ACKNOWLEDGEMENT}

I am gratifying the Lord's name for His protection and care to attend to this work. I would like to express my sincere thanks to my supervisors, Otieno, A. Charles (Ph.D.) and Warkach Kipkorir Tonui (Ph.D.) for their valuable comments, guidance and suggestions in the course of attending to this work. Appreciation to my university lecturers Professor Ang awa and Mr. Maurice Odhiambo who gave thoughtful insights during my preparations for this course. I acknowledge the efforts of my classmates who made sure that we consulted as a team for success. Special thanks to my beloved husband for his encouragement and understanding while undertaking this study. My children's support in editing and typing of the work is highly appreciated. They took it as a challenge in their academic endeavors. I also wish to thank Mrs. Jayne Ochieng` who was very close to me and through her advice, encouragement and material support the end result has been realized. I thank Jaramogi Oginga Odinga University of Science and Technology for giving me the chance 


\title{
International Advanced Research Journal in Science, Engineering and Technology
}

\author{
Vol. 7, Issue 6, June 2020
}

to study at the institution and the university support staff that facilitated me during the entire course. Thanks to National Commission on Science Technology and Innovations NACOSTI-(Kenya) for their permission to carry out a research on subsistence farming activities and food sustainability in East Alego location, Siaya, Kenya. I am indebted to everyone who touched my life spiritually or physically during this course.

God bless you all.

\section{REFERENCES}

[1] American Public Health Association, (APA), (2007). "Toward a Healthy, Sustainable Food System (Policy Num: 200712)". Retrieved 2008-08-18.

[2] Andersen, P.P. (2009). "Food Security: definition and measurement", Food Security, Vol. 1, pp. 5-7.

[3] Ariga, J., Jayne, T.S., Kibaara, B., and Nyoro, J.K. (2009). Trends and patterns in fertilizer use.

[4] Chrispeels, M., J. Sadava, D., E. (1994). "Farming Systems: Development, Productivity, and Sustainability' Plants, Genes and Agriculture. Jones and Bartlett. Pp.25-57.ISBN 978-0867208719. Clarendon Press, Oxford.

[5] Counties of Kenya, Maps-2012. - http:// open data. Go.ke/ Counties-Kenya Open Data Project.

[6] Cuavery, U.K.S. Nayak M. Girija and R. Meenakshi, (2007). Research Methodology, S. Chand and company Ltd., New Delhi.

[7] Davd, I. G., (2016). Assessing Sustainable Nutrition Security: The Role of Food Systems and Nutrition. https:// Ideas. Repec. Org > 2016318.

[8] DeJanvry, Alain; Sadoulet, Elisabeth(2011). "Subsistence farming as a safety net for food-price shock". Development in Practice. 21(4-5):472-480

[9] Foley, J.A., Ramankutty, N., Brauman, K.A., Cassidy, E.S., Gerber, J.S., Johnston, M., et al. (2011). Solutions for a cultivated planet. Nature; 478: 337-342. Pmid: 21993

[10] Godfray, H., C. Beddington, J., R. Crute, I., R. Haddad, L., Lawrence, D., Muir, J.,F. et al. (2010). Food security: the challenge of feeding 9 billion people. Science, 327, 812-818.

[11]Godfray, H., C., J. (2014). Food Security and Sustainable Intensification. https:// doi. Org/ 10.1098/rstb.2012.0273.

[12] GOK. (2005). Factors affecting sustainability of community food security projects in Kiambu County, Kenya. Https. // www. Researchgate. Net $>2696$.

[13] Government of Kenya, (2010). Agricultural sector development strategy 2010-2020.

[14] Kenya Meteorological Department, (2019). Daily Regional Forecast and Seven Day Rainfall Forecast- Kenya. Https: // www. Meteo.go.ke.

[15] Kostov, P., Lingard, J. (2004). Effects of Market Production on the rural household food: Editorial Express, htpps;)// editorial// express. Com/cg i-bin conference|download. Cg 1 ? Db-name paper.

[16] Kothari, C., R. (2004). Research Methods: Methods and Techniques, (Second Edition) New Age Techno Press.

[17] Kunlein, H. V., Receveur, O., (1996). Dietary Change and Traditional Food System of Indigenous Peoples. Centre for Nutrition and Environment of Indigenous People and School of Dietetics and Human Nutrition, Mc Gill University, Quebec, Canada.

[18]Lado, C. (1998). The transfer of agricultural technology and the development of small-scale farming in rural Africa: Case studies from Ghan, Sudan, Uganda, Zambia and South Africa. Geo Journal. Vol. 45, No. 3 (1998). Pp. 165-176. https: // www. Jstor.org> stable 41147236. Published by: Springer.

[19] Lowder, S., K. Skoet, J., Signh, S. (2014). What do we really know about the number and Distribution of farms and family farms worldwide?

[20] Mason, J., Singer, P. (2006). The Way We Eat: Why Our Food Choices Matter. London: Random House. ISBN 1-57954-889-X

[21]Michael, A. F., Baron, L. (2007). Evaluating the environmental impact of various dietary patterns combined with different food production systems. https: // www. Researchgate. Net $>6759$.

[22]Morgan, W. B., Solarz, J.A. (1994). Agricultural Crisis in Sub-Saharan Africa: Development Constraints and Policy Problems. The Geographical journal-Vol. 160. No. 1 (Mar., 1994)., pp.57-73. Published by: The Royal Geographical Society (with the Institute of British Geographers. https: // www. Jstor. Org/ stable /3060142

[23] Obiero, E. O., (2013). Social Economic Factors Affecting Farm Yield in Siaya District, Siaya County, Kenya. Pdfs. Semanticscholar org. (3): 26979. Doi: 10.1093/:/ar.46.3.269. PMID.

[24] Oso, Y. W., Onen, D., (2005). A general guide to writing research proposal and report. Option printers and publishers, Kisumu, Kenya.

[25] Pothukuchi, K., Kaufman, J., L. (1999). The food system: A stranger to the planning field. Journal of the American Planning association 66(2), 113-124.

[26] Pretty, J. (2008). Agricultural sustainability: concepts, principles and evidence. Philosophical Transactions of the Royal Society of London B: Biological Sciences. 363 (1491):447-465. Doi: 10.1098 rstb. 2007. 4163. ISSN 0962-8436-PMC2610163. PMID, 7652074.

[27] Reijntjes, C., Haverkort, B., Bayer, A., (1992). Farming for the future.

[28] Rosane, O. (2018). "Our Food Systems Are Failing Us': 100+ Academies Call for Overhaul of Food Production". Ecowatch. Retrieve May 2019

[29] Saini, A., S. Singn, R., V. Patel, R., K. (1989). Credit management through dairying, Financing Agriculture, 21; 6-10.

[30] Sandhu, H. S., Wratten, S. D., Cullen, R., (2010). Organic agricultural ecosystem services. Environmental Science and Policy. 13 (1): 1-7, do: 10.101016/j.envsci- 2009.11.002-ISSN-1462-9011.

[31] Schelesinger, W., H. (1977). Carbon balance in terrestrial detritus, Annual Review of Ecology and Systematics, 8, 51-81.

[32] Siaya County Integrated Development Plan 2013-2017.

[33] Siaya Website Census Report 2009.

[34] Sombroek, W. G., Braun, H. M. H., Van derpouw, B. J. A., ( 1982). The exploratory Soil Map and agro-climatic zone map of Kenya, Scale 1: 1 million. Exploratory Soil Survey No. EI. Kenya soil Survey Nairobi.

[35] Steinfeld H.; Gerber P.; Wassenaar T.; Castel V.; Rosales M.; de Haan C. (2006). "Livestock's Long Shadow: Environmental Issues and Options". FAO. Retrieved 13 December 2017.

[36] Wanjama, D. Graham, S. (2002). Evaluation of Food Security Intervention in Makueni, Kenya: Food and Agricultural Organization of the United States. Report on the IFAD V: Plan of Action (2000-2002).

[37] Winrock, (1992). An assessment of animal agriculture in Sub -Saharan-Africa. Winrock International: Morriton, USA.

[38] World Bank, (2005). Agriculture Investment Source Book; Agriculture and Rural Development World Bank Washington DC. 508 pp.

[39] World Health Organisation, (2004). "Global Strategy on Diet, Physical Activity and Health." Copy of the strategy endorsed by the World Health Assembly. Retrieved on: 2009-6-19. 